University of South Florida

DIGITAL COMMONS

Digital Commons @ University of

@ UNIVERSITY OF SOUTH FLORIDA

South Florida

$10-1986$

\title{
On the Baroclinic Response of the Zonal Pressure Gradient in the Equatorial Atlantic Ocean
}

\author{
Robert H. Weisberg \\ North Carolina State University at Raleigh, weisberg@marine.usf.edu \\ T. J. Weingartner \\ North Carolina State University
}

Follow this and additional works at: https://digitalcommons.usf.edu/msc_facpub

\section{Scholar Commons Citation}

Weisberg, Robert H. and Weingartner, T. J., "On the Baroclinic Response of the Zonal Pressure Gradient in the Equatorial Atlantic Ocean" (1986). Marine Science Faculty Publications. 427.

https://digitalcommons.usf.edu/msc_facpub/427

This Article is brought to you for free and open access by the College of Marine Science at Digital Commons @ University of South Florida. It has been accepted for inclusion in Marine Science Faculty Publications by an authorized administrator of Digital Commons @ University of South Florida. For more information, please contact digitalcommons@usf.edu. 


\title{
On the Baroclinic Response of the Zonal Pressure Gradient in the Equatorial Atlantic Ocean
}

\author{
R. H. WeISBERG ${ }^{1}$ and T. J. WeINGARTNER ${ }^{1}$ \\ Department of Marine, Earth, and Atmospheric Sciences, North Carolina State University, Raleigh
}

\begin{abstract}
Temperature time series obtained from surface moorings deployed along the equator in the Atlantic Ocean during the Seasonal Response of the Equatorial Atlantic Experiment and the Programme Françaıs Océan et Climat dans l'Atlantique Equatorıal were used to investigate the baroclinic response of the zonal pressure gradient due to the sloping isopycnals. The zonal pressure gradient evolved as a complicated function of time, depth, and zonal position. The most rapid and spatially inhomogeneous varuations corresponded to periods of rapidly changing easterly wind stress. Following these periods the baroclınic response due to the sloping isopycnals was observed to overshoot its intended equilibrium before relaxing to it. In so doing, it tended to buffer pressure gradient variations at the depth of the Equatorial Undercurrent (EUC). Over much of the year the isopycnal slopes opposed the surface slope. After the winds relaxed in winter, however, the isopycnal slopes reversed and acted in concert with the surface slope, thereby enhancing the pressure gradient at the depth of the EUC relative to that at the surface. This reversal might be important in maintaining the EUC during times of weak easterly wind stress. The vertical structure of the zonal pressure gradient varied with the depth of the thermocline. When the winds were weak and the thermocline was shallow, the baroclinic response of the zonal pressure gradient due to the sloping isopycnals was primarily effected in the upper $50 \mathrm{~m}$. After the winds intensified and the thermocline deepened the baroclinic response extended down to at least $150 \mathrm{~m}$.
\end{abstract}

\section{INTRODUCTION}

Knowledge of the zonal pressure gradient along the equator (ZPG) is fundamentally important to understanding the dynamics of the Equatorial Undercurrent (EUC) and the associated circulation in the meridional plane. The ZPG ensues as the prevailing easterly winds accumulate water along the South American continent, thereby establishing an eastward pressure gradient force at the surface. In conjunction with this the subsurface isopycnals slope upward from west to east. The westward pressure gradient force associated with their vertical integral eventually compensates the eastward force of the surface slope. Compensation is incomplete within the thermocline, and the resultant eastward pressure gradient force gives rise to the EUC. Previous studies of the near-surface ZPG in the equatorial Atlantic [Katz et al., 1977, Lass et al., 1983], derived from a small ensemble of limited duration measurements, showed a ZPG approximately in phase with the easterly wind stress component which is strongest in boreal summer and weakest in winter.

During the Seasonal Response of the Equatorial Atlantic (SEQUAL) Experiment and the Programme Français Océan et Climat dans l' Atlantique Equatorial (FOCAL), approximately, 18 months (March 1983 to September 1984) of temperature data were collected from a zonal array of moored current meters. These data are used herein to describe the evolution of the baroclinic response of the ZPG along the equator caused by the sloping isopycnals.

The paper is organized as follows. Section 2 reviews previous measurements of the equatorial ZPG from the world's oceans. It shows that the surface pressure gradient is effectively compensated at a depth slightly below the high-speed core of the EUC. In the Atlantic Ocean this depth lies between

\footnotetext{
da, Saint Petersburg.

Copyright 1986 by the American Geophysical Union.

${ }^{1}$ Now at Department of Marine Science, University of South Flori-
75 and $100 \mathrm{~m}$. In anticipation of our own results, the review highlights observations of a reversal in the zonal pressure gradient below the EUC core typically in a region of steady eastward flow. Section 3 describes the field program, the data, and the method for computing the baroclinic response. The seasonal evolution and vertical structure of this response is then discussed in relation to zonal wind stress forcing in section 4. The observed baroclinic response differs substantially from the sinusoidal evolution as surmised from the limited climatology. These differences relate to the rapidity in which the easterly wind stress varies in a given year in relation to the slowly varying climatologically averaged winds. The continuous and synoptic baroclinic response data show equally rapid variations with a tendency to overshoot the equilibrium value necessary to balance the wind stress. One important consequence is that over a portion of the basin, following the abatement of easterly wind stress, the baroclinic response by the isopycnals reverses from a westward directed force to an eastward one. Adding this part to the surface slope results in a larger eastward directed pressure gradient force at the depth of the EUC at a time when the surface slope alone would imply a much smaller value [Katz et al., 1986]. The opposite occurs following rapid intensification in easterly wind stress. Hence by virtue of the baroclinic buffering due to isopycnal slopes, the variations in the ZPG at the depth of the EUC are much smaller than those at the surface throughout the year. Additionally, it is shown that the temporal variation of isopycnal slopes does not proceed uniformly with depth, nor is it limited to within $100 \mathrm{~m}$. As a consequence a westward pressure gradient force may develop beneath the thermocline during part of the year. These findings are discussed in section 5 and the paper is summarized in section 6 .

\section{BACKGROUND}

The ZPG was a focal point of tropical oceanography well before the existence of equatorial undercurrents was recognized. Montgomery and Palmen, [1940] initially sought to explain the North Equatorial Countercurrent (in both the Pacific and Atlantic oceans) as a consequence of the balance be- 
TABLE 1. Estimates of the Zonal Pressure Gradient Force Along the Equator for the World's Oceans

\begin{tabular}{|c|c|c|c|c|c|c|}
\hline Source & Date & Longitude & $\begin{array}{c}\text { Depth, } \\
\text { dbar }\end{array}$ & $\begin{array}{c}\text { Reference } \\
\text { Depth, } \\
\text { dbar }\end{array}$ & $-\frac{1}{\rho} \frac{\partial p}{\partial x}$ & $\begin{array}{l}10^{-3} \\
\text { dyn/g }\end{array}$ \\
\hline & & cific Ocean & & & & \\
\hline \multirow{4}{*}{$\begin{array}{c}\text { Montgomery and } \\
\text { Palmen }[1940]\end{array}$} & Composite & $131^{\circ} \mathrm{E}-99^{\circ} \mathrm{W}$ & 0 & 1000 & 4.5 & \\
\hline & & & 100 & 1000 & 1.9 & \\
\hline & & & 200 & 1000 & 0.4 & \\
\hline & & & 300 & 1000 & 0.0 & \\
\hline \multirow[t]{2}{*}{ Austin [1958] } & Composite & $170^{\circ} \mathrm{W}-100^{\circ} \mathrm{W}$ & 0 & 700 & 5.0 & \\
\hline & & & 300 & 700 & $\approx 0.0$ & \\
\hline \multirow[t]{3}{*}{ Knauss [1966] } & IV/1958 & $140^{\circ} \mathrm{W}-98^{\circ} \mathrm{W}$ & 0 & 1000 & 5.4 & \\
\hline & & & $\approx 75$ & 1000 & 2.6 & \\
\hline & & & $\approx 225$ & 1000 & \pm 0.1 & \\
\hline \multirow{4}{*}{$\begin{array}{c}\text { Taft et al. } \\
{[1974]}\end{array}$} & IV/1971 & $159^{\circ} \mathrm{W}-150^{\circ} \mathrm{W}$ & 0 & 1500 & 6.4 & \\
\hline & & & 100 & 1500 & 5.0 & \\
\hline & & & 140 & 1500 & 1.3 & \\
\hline & & & 200 & 1500 & -1.2 & \\
\hline \multirow[t]{21}{*}{ Tsuchiya [1979] } & II, III/1967 & $130^{\circ} \mathrm{W}-97^{\circ} \mathrm{W}$ & 0 & 500 & 2.6 & $(1.5)^{*}$ \\
\hline & & & 50 & 500 & 1.5 & $(0.7)$ \\
\hline & & & 100 & 500 & 0.4 & $(0.7)$ \\
\hline & IV, V/1967 & & 0 & 500 & -0.8 & (2.1) \\
\hline & & & 50 & 500 & 0.2 & (1.2) \\
\hline & & & 100 & 500 & 0.4 & (0.5) \\
\hline & VI, VII/1967 & & 0 & 500 & 5.1 & $(0.5)$ \\
\hline & & & 50 & 500 & 2.4 & $(0.8)$ \\
\hline & & & 100 & 500 & 0.3 & $(0.3)$ \\
\hline & VIII, IX/1967 & & 0 & 500 & 2.9 & (0.9) \\
\hline & & & 50 & 500 & 0.6 & $(0.3)$ \\
\hline & & & 100 & 500 & -0.5 & $(0.1)$ \\
\hline & $\mathrm{X}, \mathrm{XI} / 1967$ & & 0 & 500 & 2.8 & $(0.8)$ \\
\hline & & & 50 & 500 & 2.7 & $(0.2)$ \\
\hline & & & 100 & 500 & 0.1 & $(0.4)$ \\
\hline & $\mathrm{XII} / 67-\mathrm{I} / 68$ & & 0 & 500 & 4.3 & (2.2) \\
\hline & & & 50 & 500 & 4.2 & (2.1) \\
\hline & & & 100 & 500 & 2.0 & (1.4) \\
\hline & II-IV/1968 & & 0 & 500 & -0.1 & (1.8) \\
\hline & & & 50 & 500 & -0.5 & (1.3) \\
\hline & & & 100 & 500 & -1.0 & $(0.5)$ \\
\hline \multirow[t]{5}{*}{ Halpern [1980] } & IV-V/1979 & $153^{\circ} \mathrm{W}-133^{\circ} \mathrm{W}$ & 0 & 270 & 5.4 & $(0.6)$ \\
\hline & & $132^{\circ} \mathrm{W}-120^{\circ} \mathrm{W}$ & 0 & 270 & 3.5 & (1.3) \\
\hline & & $120^{\circ} \mathrm{W}-110^{\circ} \mathrm{W}$ & 0 & 270 & 0.5 & (1.4) \\
\hline & & $132^{\circ} \mathrm{W}-110^{\circ} \mathrm{W}$ & 270 & 400 & -0.5 & \\
\hline & & & 270 & 400 & -0.25 & \\
\hline \multirow{31}{*}{$\begin{array}{l}\text { Mangum and } \\
\text { Hayes }[1984] \dagger\end{array}$} & $11 / 79$ & $150^{\circ} \mathrm{W}-110^{\circ} \mathrm{W}$ & 0 & 1000 & 4.0 & \\
\hline & & & 100 & 1000 & 2.0 & \\
\hline & & & 200 & 1000 & -0.6 & \\
\hline & IV $/ 79$ & & 0 & 1000 & 2.0 & \\
\hline & & & 100 & 1000 & 0.4 & \\
\hline & & & 200 & 1000 & -0.8 & \\
\hline & $\mathrm{VI} / 79$ & & 0 & 1000 & 5.2 & \\
\hline & & & 100 & 1000 & 2.0 & \\
\hline & & & 200 & 1000 & 0.6 & \\
\hline & VII/79 & & 0 & 1000 & 3.5 & \\
\hline & & & 100 & 1000 & 1.2 & \\
\hline & & & 200 & 1000 & -0.1 & \\
\hline & $\mathrm{X} / 79$ & & 0 & 1000 & 5.7 & \\
\hline & & & 100 & 1000 & 3.0 & \\
\hline & & & 200 & 1000 & 0.8 & \\
\hline & $\mathrm{III} / 80$ & & 0 & 1000 & 4.0 & \\
\hline & & & 100 & 1000 & 1.0 & \\
\hline & & & 200 & 1000 & -0.4 & \\
\hline & IV $/ 80$ & & 0 & 1000 & 7.6 & \\
\hline & & & 100 & 1000 & 4.0 & \\
\hline & & & 200 & 1000 & 1.1 & \\
\hline & VII/81 & & 0 & 1000 & 4.2 & \\
\hline & & & 100 & 1000 & 2.0 & \\
\hline & & & 200 & 1000 & 0.5 & \\
\hline & Mean for non- & & 0 & 1000 & 4.5 & \\
\hline & El Niño years & & 100 & 1000 & 2.0 & \\
\hline & & & 200 & 1000 & 0.0 & \\
\hline & IV/82 & & 0 & 1000 & 5.0 & \\
\hline & & & 100 & 1000 & 3.1 & \\
\hline & & & 200 & 1000 & 1.0 & \\
\hline & IX/82 & & 0 & 1000 & 5.6 & \\
\hline
\end{tabular}


TABLE 1. (continued)

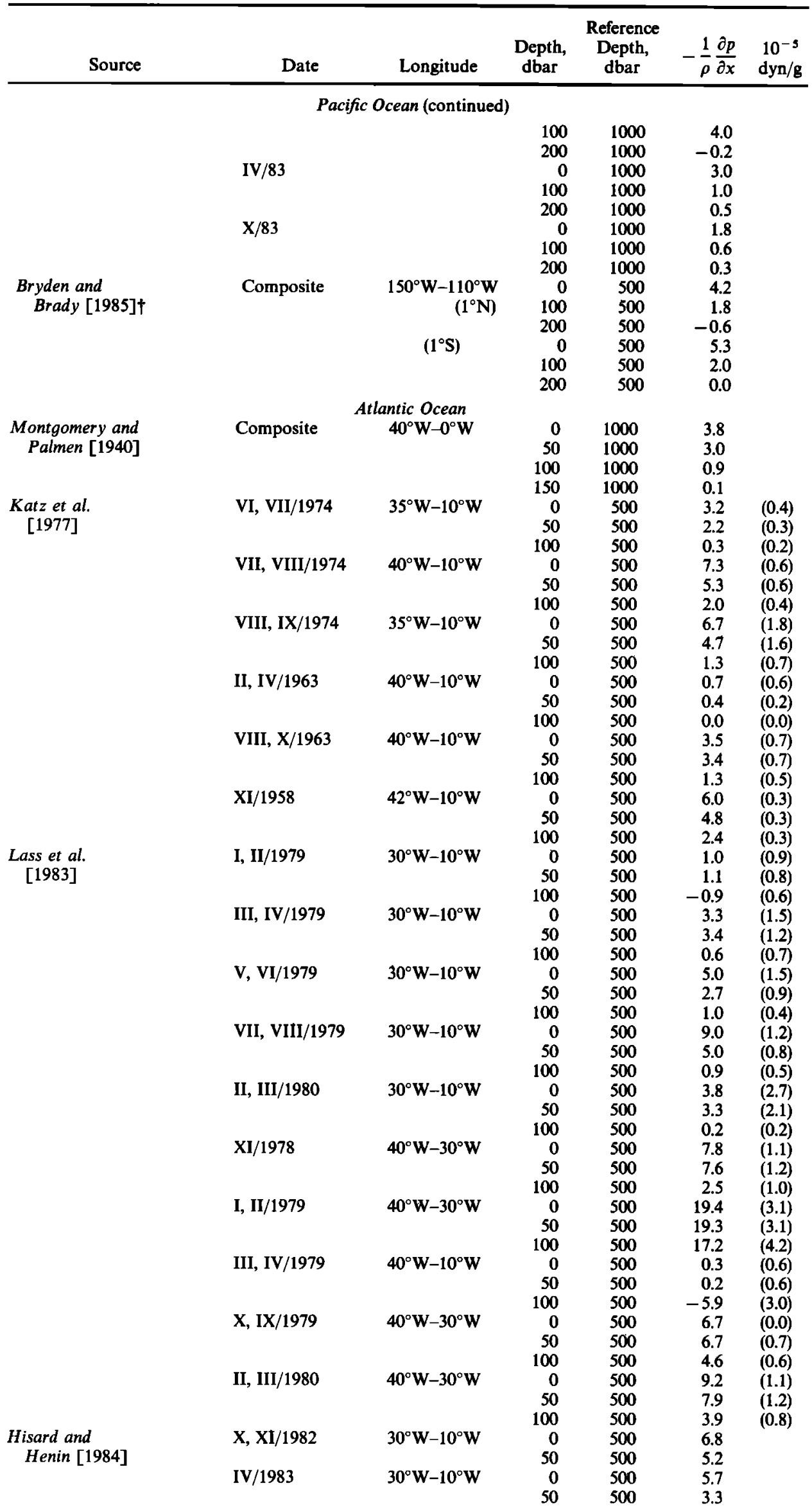


TABLE 1. (continued)

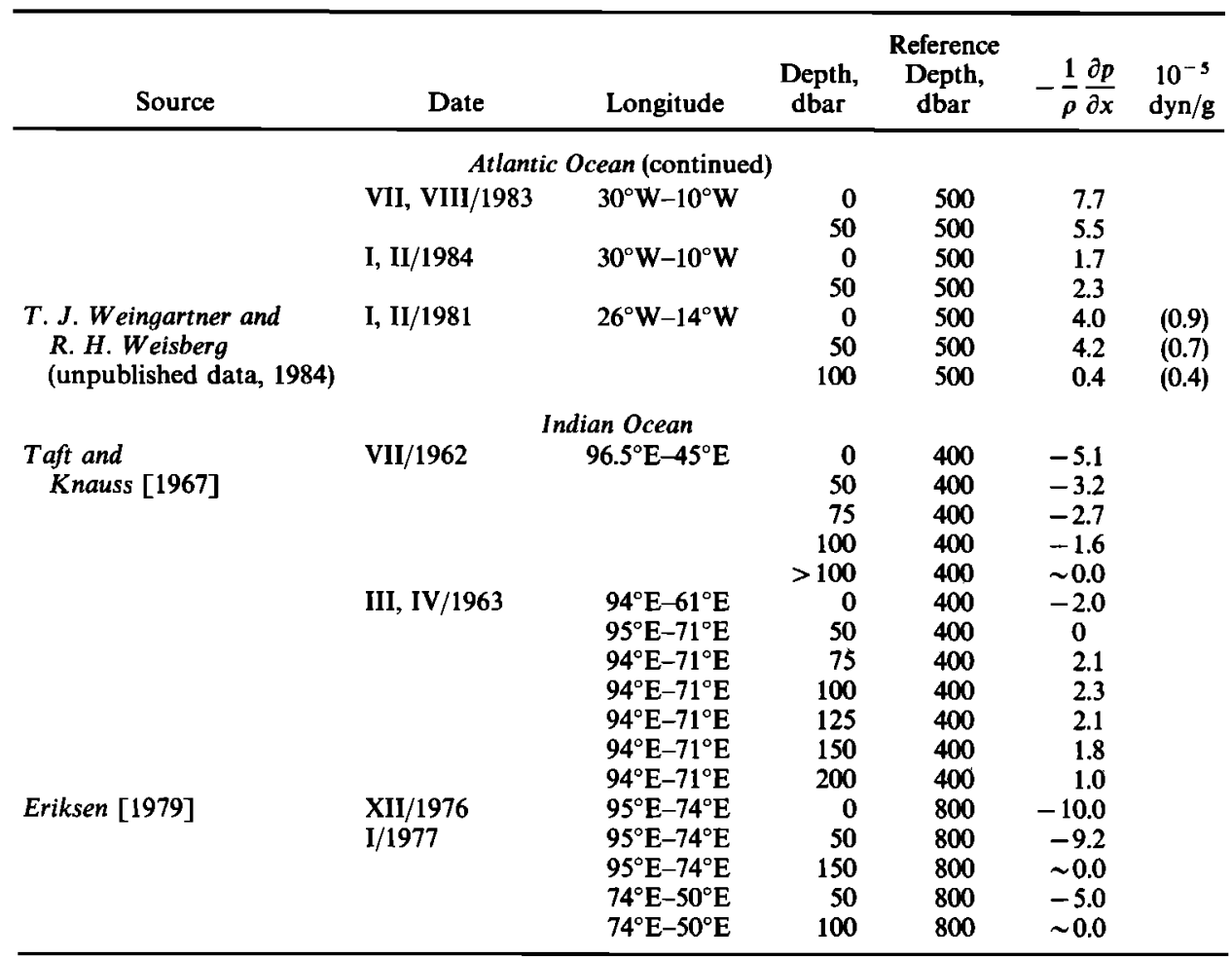

"Numbers in parentheses are the standard errors of the slopes of the linear regression equations.

$\dagger$ The listed values have been estimated from the figures provided in the original paper.

tween the ZPG, lateral friction, and the Coriolis acceleration. Utilizing the hydrographic data then available, they concluded that the ZPG vanishes at $100 \mathrm{~m}$ in the Atlantic Ocean and at $300 \mathrm{~m}$ in the Pacific Ocean. The discovery or rediscovery of equatorial undercurrents in the Pacific [Cromwell et al., 1954] and Atlantic [Voigt, 1961; Metcalf et al., 1962] and early attempts to explain their existence (see Philander [1973] and Gill [1975] for reviews) intensified interest in the ZPG. Yet in spite of these stimuli, only a small number of observations exist. These observations, from the world's oceans, are summarized below and in Table 1.

In the Pacific Ocean the mean gradient computed west of, say, $110^{\circ} \mathrm{W}$ [Austin, 1958; Knauss, 1966; Taft et al., 1974; Halpern, 1980; Mangum and Hayes, 1984; Bryden and Brady, 1985] decreases from a maximum at the surface to zero by about $200 \mathrm{~m}$. Tsuchiya [1979] found no significant gradients at and below $100 \mathrm{~m}$ between approximately $130^{\circ} \mathrm{W}$ and $95^{\circ} \mathrm{W}$ in seven surveys conducted throughout the year. The decreasing depth of zero gradient from west to east coincides with the shoaling of the thermocline and the EUC core from around $120 \mathrm{~m}$ at $150^{\circ} \mathrm{W}$ to around $60 \mathrm{~m}$ at $110^{\circ} \mathrm{W}$. The data indicate that at the surface, significant pressure gradient forces are always eastward, while reversals occur at depth. For example, 5 of the 12 cases presented by Mangum and Hayes [1984] show a westward pressure gradient force below $150 \mathrm{~m}$. Bryden and Brady's [1985] results suggest a weak mean westward pressure gradient force below $150 \mathrm{~m}$ between $150^{\circ} \mathrm{W}$ and $110^{\circ} \mathrm{W}$.

In the Atlantic Ocean the wind stress veers increasingly easterly west of $10^{\circ} \mathrm{W}$, while it is southerly or southwesterly to the east of that longitude. Consequently, the sea surface tends to slope upward both to the east and to the west of $10^{\circ} \mathrm{W}$. Typically, estimates of the eastward pressure gradient force in the Atlantic are confined to the west of $10^{\circ} \mathrm{W}$. The compi- lation of pressure gradients provided by Katz et al. [1977] reveals no significant values at $100 \mathrm{~m}$ between $40^{\circ} \mathrm{W}$ and $10^{\circ} \mathrm{W}$, except in November 1958 and July-August 1974. For these times the $100-\mathrm{m}$ pressure gradient was approximately one-third the surface value, which is still indicative of a strong baroclinic response at $100 \mathrm{~m}$. The quasi-synoptic data of Lass et al. [1983] and the mean annual results described by Merle and Arnault [1985] (reproduced in Figure 1) indicate a vanishing ZPG at $100 \mathrm{~m}$ for the central Atlantic $\left(30^{\circ} \mathrm{W}\right.$ to $\left.10^{\circ} \mathrm{W}\right)$. Significant gradients (both eastward and westward) can exist at this depth between $40^{\circ} \mathrm{W}$ and $30^{\circ} \mathrm{W}$. As in the Pacific, the eastward shoaling of the compensation depth correlates with that of the thermocline and EUC core. A zonal expendable bathythermograph (XBT) profile in January-February 1981 also shows no significant gradient below $100 \mathrm{~m}$ (T. J. Weingartner and R. H. Weisberg, unpublished data, 1984).

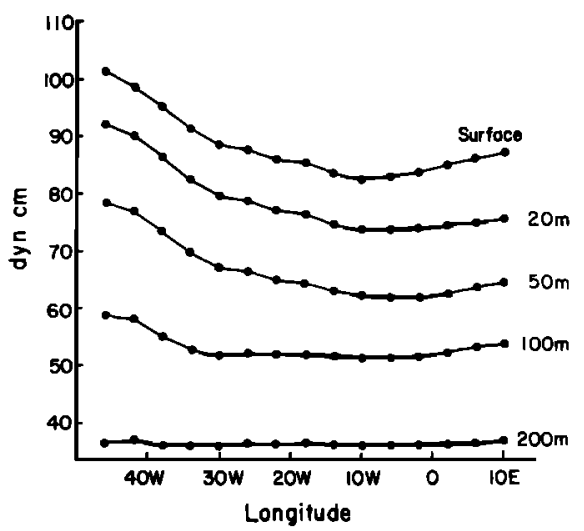

Fig. 1. Mean annual dynamic height along the equator (from $2^{\circ} \mathrm{N}$ to $2^{\circ} \mathrm{S}$ ) in dynamic centimeters relative to $500 \mathrm{dbar}$ [from Merle and Arnault, 1985]. 


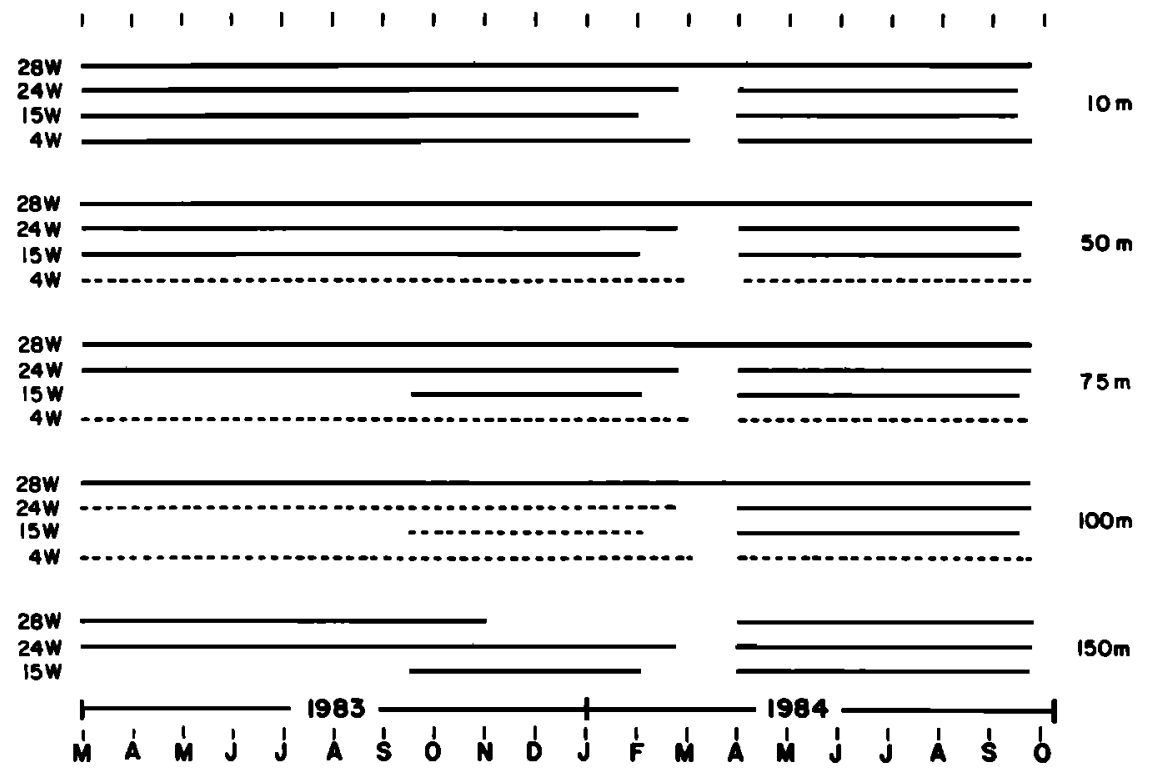

Fig. 2. Time lines for temperature data as a function of longitude and depth. Dashed lines indicate series which were depth interpolated. Tick marks on the axis coincide with the beginning of each month.

Only a few profiles are available from the Indian Ocean. Taft and Knauss [1967] found no significant gradients below $100 \mathrm{~m}$ in July 1962 when the southwest monsoon was well developed. During their March-April 1963 transect when the winds were weak and variable, the pressure gradient force in the eastern half of the basin was westward at the surface, reversed below $50 \mathrm{~m}$, attained a maximum at $100 \mathrm{~m}$, and vanished below $200 \mathrm{~m}$. For the western half of the basin, the only significant pressure gradient forces found were eastward at $50 \mathrm{~m}$ and $75 \mathrm{~m}$. These results are interesting because they demonstrate that subsurface gradients may not be in phase with those at the surface during a period of weak and variable winds. Finally, Eriksen's [1979] data show negligible gradients below $100 \mathrm{~m}(150 \mathrm{~m})$ in the western (eastern) Indian Ocean in December 1976 to January 1977.

The preceding literature survey indicates that along the equator the baroclinic response due to the isopycnal slopes is such that seasonal variations of the surface pressure gradient are compensated at a depth slightly below the region of maximum temperature gradient in the thermocline and the EUC core. For the central Atlantic $\left(30^{\circ} \mathrm{W}\right.$ to $\left.10^{\circ} \mathrm{W}\right)$ this depth lies between $75 \mathrm{~m}$ and $100 \mathrm{~m}$. In anticipation of our results we draw attention to the observations of a westward pressure gradient force below the compensation depth. For the Pacific, Bryden and Brady [1985] indicate that within $1^{\circ}$ of the equator the pressure gradient force opposes the eastward flow beneath the core of the EUC. While the flow is against the pressure gradient force, this scenario is precisely that suggested by Arthur [1960], who hypothesized that under steady state conditions the vertical profile of zonal velocity can be calculated from a balance between the ZPG and the vertical diffusion of zonal momentum.

\section{Data}

The temperature time series used in this analysis were obtained from surface buoyed current meter moorings located along the equator at $28^{\circ} \mathrm{W}, 24^{\circ} \mathrm{W}, 15^{\circ} \mathrm{W}$, and $4^{\circ} \mathrm{W}$. Figure 2 summarizes the temperature time series as a function of depth and longtitude. Pressure gradients were computed between all pairs with concurrent time series at depths of $10 \mathrm{~m}, 50 \mathrm{~m}, 75$ $\mathrm{m}, 100 \mathrm{~m}$, and $150 \mathrm{~m}$. However, not all moorings had meters at these depths. In order to provide a set of common depths from which to compute temperature gradients, the data were linearly interpolated to the desired depth. These series are represented by dashed lines in the figure. Thus the $100-\mathrm{m}$ temperature time series at $15^{\circ} \mathrm{W}$ and $24^{\circ} \mathrm{W}$ were generated from the 75-m and 150-m time series for the March 1983 to March 1984 period. Similarly, temperature at $4^{\circ} \mathrm{W}$ recorded at $10 \mathrm{~m}, 35 \mathrm{~m}, 60 \mathrm{~m}, 85 \mathrm{~m}$, and $110 \mathrm{~m}$ were interpolated to $50 \mathrm{~m}$, $75 \mathrm{~m}$, and $100 \mathrm{~m}$.

Assuming that atmospheric pressure is horizontally uniform, the zonal pressure gradient at a particular level surface, $H$, is

$$
\frac{\partial p}{\partial x}=\rho_{\eta} g \frac{\partial \eta}{\partial x}+g \int_{H}^{\eta} \frac{\partial \rho}{\partial x} d z
$$

where $\rho_{\eta}$ is the surface density, $\partial \eta / \partial x$ is the surface slope, $g$ is gravity, and $p$ is pressure. The second term on the right-hand side is the baroclinic response of the surface pressure gradient due to the sloping isopycnals. Since the instruments were suspended at equal distances from the free surface, we can not measure $\partial \rho / \partial x$ directly on a level surface. The error involved in the density gradient measured along a fixed depth as opposed to a level surface is $(\partial \rho / \partial z)(\partial \eta / \partial x)$. This error when divided by $\partial \rho / \partial x$ along a level surface shows that the relative error equals the free surface slope divided by the isopycnal slope, which is much less than 1 . Instrument tilt would result in similarly small errors. The baroclinic response at any particular depth due to the sloping isopycnals was obtained by cumulative trapezoidal integration of the zonal density gradient from the surface to that depth. Gradients were computed between all possible pairs of moorings.

Density was estimated using 10-day low pass-filtered temperature time series and the simplified equation of state: $\rho=$ $\rho_{0}\left[1+\alpha\left(T-T_{0}\right)\right]$, where $\rho_{0}$ and $T_{0}$ are a reference density and temperature, respectively. The coeflicient of thermal expansion, $\alpha$, varies with depth and temperature and was determined at each depth from a linear regression on temperature. 

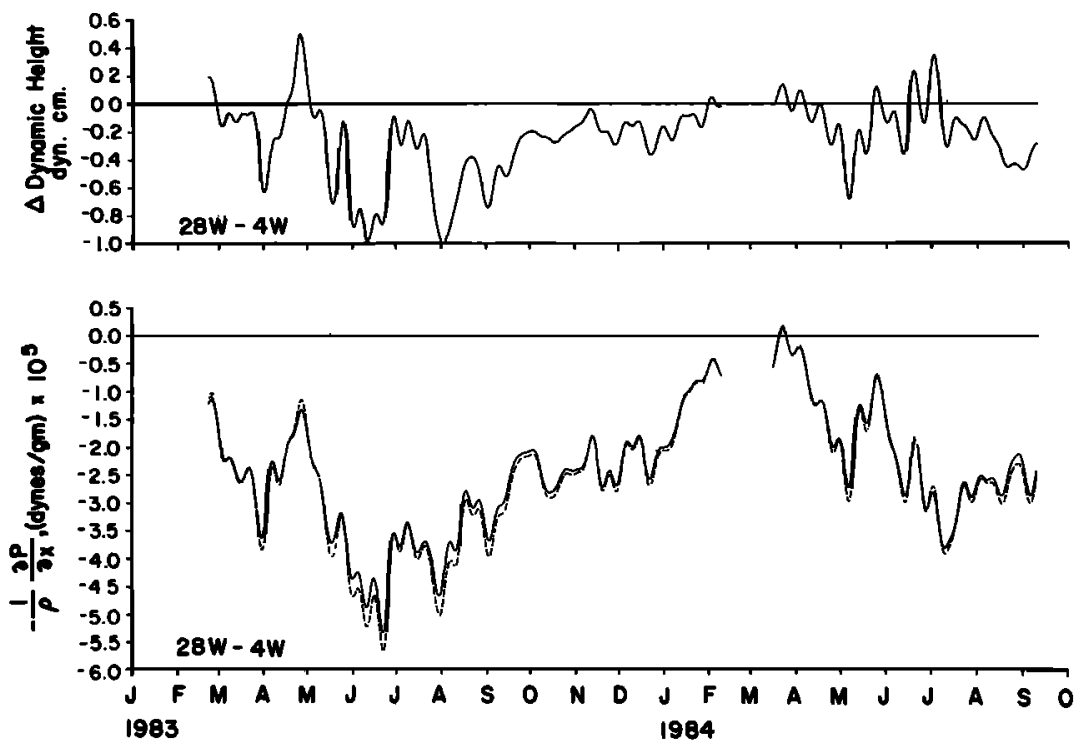

Fig. 3. Comparison of pressure gradient computation derived from temperature/salinity and temperature only. In the lower panel the actual values of the pressure gradients are shown. The solid line is for that based on temperature alone. The dashed line is obtained from a $T / S$ relationship. The difference between the two is expressed as a difference in dynamic height and is shown in the upper panel. See text for discussion. Tick marks on the time axis coincide with the fifteenth day of each month.

To ascertain the influence of salinity on the calculations of the zonal pressure gradient, a comparison was made between the above formulation and pressure gradients derived using the temperature/salinity $(T / S)$ relationship for the central equatorial Atlantic from the atlas of Emery and Dewar [1982]; the data used were taken from their Atlantic area 1. A quadratic regression of salinity against temperature was fit by least squares over the temperature range of $27.5^{\circ} \mathrm{C}$ to $13^{\circ} \mathrm{C}$. In conjunction with the temperature time series, the regression generated a salinity time series from which density was computed using the equation of state of seawater [United Nations Educational, Scientific, and Cultural Organization (UNESCO), 1981]. Our comparison was madè between the $28^{\circ} \mathrm{W}$ and $4^{\circ} \mathrm{W}$ moorings. Figure 3 illustrates the results of this comparison at a depth of $75 \mathrm{~m}$, where the largest absolute difference between the gradients was found. The ZPG time series calculated with and without salinity are shown in the lower panel. Both are essentially the same. The difference between the two time series can also be expressed as the dynamic height difference between the two longitudes relative to an an arbitrary reference level as shown in the upper panel. The mean difference is $-9.3 \times 10^{-7} \mathrm{dyn} / \mathrm{g}$, where the sign implies that the $T / S$ derived values are more negative. In terms of dynamic topography this difference corresponds to a change of less than 0.3 dyn $\mathrm{cm}$. Furthermore, the relative differences between temperature and $T / S$-derived pressure gradients decrease with depth, i.e., $16 \%$ at $10 \mathrm{~m}, 7 \%$ at $50 \mathrm{~m}, 4 \%$ at $75 \mathrm{~m}$, and $0.5 \%$ at 100 m.

While this approach demonstrates that the neglect of salinity in computing pressure gradients does not seriously impair the estimation, spatial and seasonal variations in the $T / S$ relationship have been ignored. Emery and Dewar [1982] show that spatial variations in $T / S$ result in root-mean-squared differences in dynamic height (0/500 dbar) of 1 to $3 \mathrm{dyn} \mathrm{cm}$ for the central equatorial Atlantic. In the Gulf of Guinea, Merle and Arnault [1985] found that a constant $T / S$ relationship as opposed to a seasonally varying one resulted in dynamic height differences $(0 / 500 \mathrm{dbar})$ of $1 \mathrm{dyn} \mathrm{cm}$. In summary, the largest error (due to spatially varying $T / S$ ) translates to a pressure gradient error between $28^{\circ} \mathrm{W}$ and $4^{\circ} \mathrm{W}$ of $0.3 \times 10^{-5}$ dyn/g, which in Figure 3 and subsequent figures is negligible.

\section{Results}

In response to large-scale changes in easterly wind stress, isopycnal (isotherm) slopes evolve giving rise to the baroclinic adjustment of the ZPG. This is illustrated in Figure 4, which shows easterly wind stress component and temperature time series low pass-filtered to remove fluctuations at time scales shorter than 10 days. The wind data are from Saint Peter and Saint Paul rocks (SPPR) located at $1^{\circ} \mathrm{N}, 2^{\circ} \mathrm{W}$ (S. L. Garzoli, personal communication, 1984) and from a surface mooring located at the equator, $24^{\circ} \mathrm{W}$ (R. E. Payne, personal communication, 1984). The temperature data at 50-m depth are from surface moorings on the equator at $24^{\circ} \mathrm{W}$ and $15^{\circ} \mathrm{W}$. During 1983 the easterly wind stress at SPPR increased rapidly beginning in mid-April and then remained well developed through November. Upon resumption of the record in January 1984 , the easterly wind stress was weak and remained so until mid-May 1984, when it again intensified rapidly. The $24^{\circ} \mathrm{W}$ data fill in the record gap and show that the seasonal relaxation in easterly wind stress was also rapid beginning in mid-December 1983. As was reported by Garzoli and Katz [1984], Katz [1984], Payne [1984], and Katz et al. [1986], the winds at SPPR are representative of those over a large zonal extent of the equatorial Atlantic.

The wind stress intensification times of mid-April 1983 and mid-May 1984 serve as benchmarks after which rapid variations in temperature are observed. The temperature at both longitudes first decreases and then increases as the isotherms within the thermocline shoal and then deepen [Weisberg and Colin, 1986]. This sequential behavior increases systematically both in magnitude and duration to the east [Weisberg and Tang, 1985], so that while the thermocline is deepening at $24^{\circ} \mathrm{W}$ it is still shoaling at $15^{\circ} \mathrm{W}$. It is during this antagonistic 


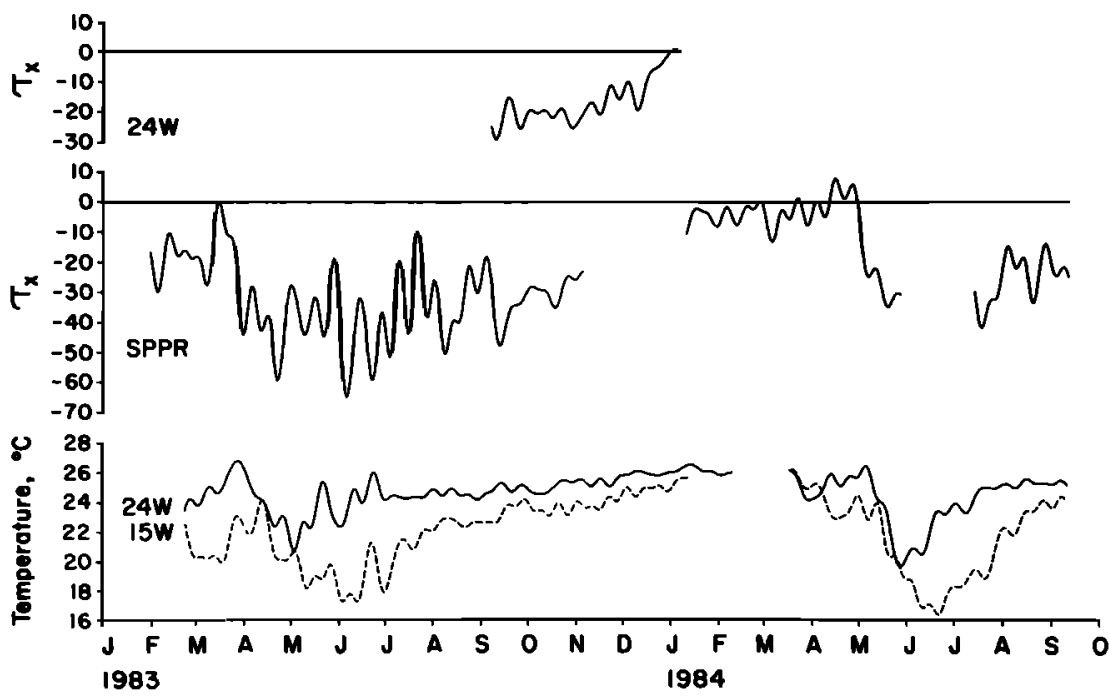

Fig. 4. Time series of zonal wind pseudo-stress from Saint Peter and Saint Paul rocks and the $24^{\circ} \mathrm{W}$ mooring (upper panel). The lower panel contains the time series of temperature at $50 \mathrm{~m}$ from $24^{\circ} \mathrm{W}$ (solid curve) and $15^{\circ} \mathrm{W}$ (dashed curve). Tick marks on the time axis coincide with the fifteenth day of each month.

shoaling/deepening period that the zonal isopycnal slope increases rapidly to its maximum value. The eventual deepening of the thermocline at $15^{\circ} \mathrm{W}$ then decreases the isopycnal slope to a relatively steady value. In 1983 this relatively steady value was sustained through mid-December, when the easterly wind stress relaxed and the thermocline underwent a sequence of deepening followed by shoaling.

Corresponding time series for the baroclinic adjustment of the ZPG are shown in Figure 5 for the station pairs $28^{\circ} \mathrm{W}$ and $24^{\circ} \mathrm{W}, 28^{\circ} \mathrm{W}$ and $15^{\circ} \mathrm{W}, 15^{\circ} \mathrm{W}$ and $4^{\circ} \mathrm{W}$, and $28^{\circ} \mathrm{W}$ and $4^{\circ} \mathrm{W}$. Finite differencing over increasing station separation acts to filter high-wave number structure and to obscure phase differences among the mooring pairs due to propagation. Both the similarities and dissimilarities between the different station pairs are important in understanding the pressure field variations along the equator.

\section{Annual Cycle}

The most complete station pairs are $28^{\circ} \mathrm{W}$ and $24^{\circ} \mathrm{W}$ and $28^{\circ} \mathrm{W}$ and $4^{\circ} \mathrm{W}$. Consider the shorter separation first. The baroclinic response at all of the depths shown $(50 \mathrm{~m}, 75 \mathrm{~m}$, and $100 \mathrm{~m}$ ) are energetic over a broad range of frequencies; however, the annual cycle is the dominant feature. Beginning in mid-April 1983 we observe an increase in the westward directed pressure gradient force (per unit mass) due to isopycnal slopes. Underlying the high-frequency oscillations, a maximum is reached in June followed by a gradual decline to relatively steady values from late summer through fall. That the wind stress and ZPG are both relatively steady during this period suggests that they are in approximate equilibrium.

A more rapid decline and reversal to an eastward directed force occurs after the relaxation of easterly wind stress at the end of the year (see Figure 4). A rapid increase to a large westward directed force again occurs following the mid-May 1984 easterly wind stress intensification. Similar behavior is observed over the larger separation $28^{\circ} \mathrm{W}-4^{\circ} \mathrm{W}$ with two notable exceptions. First, the high-frequency structure is largely reduced, and second, the response exhibits a somewhat different character immediately following the wind stress bench-
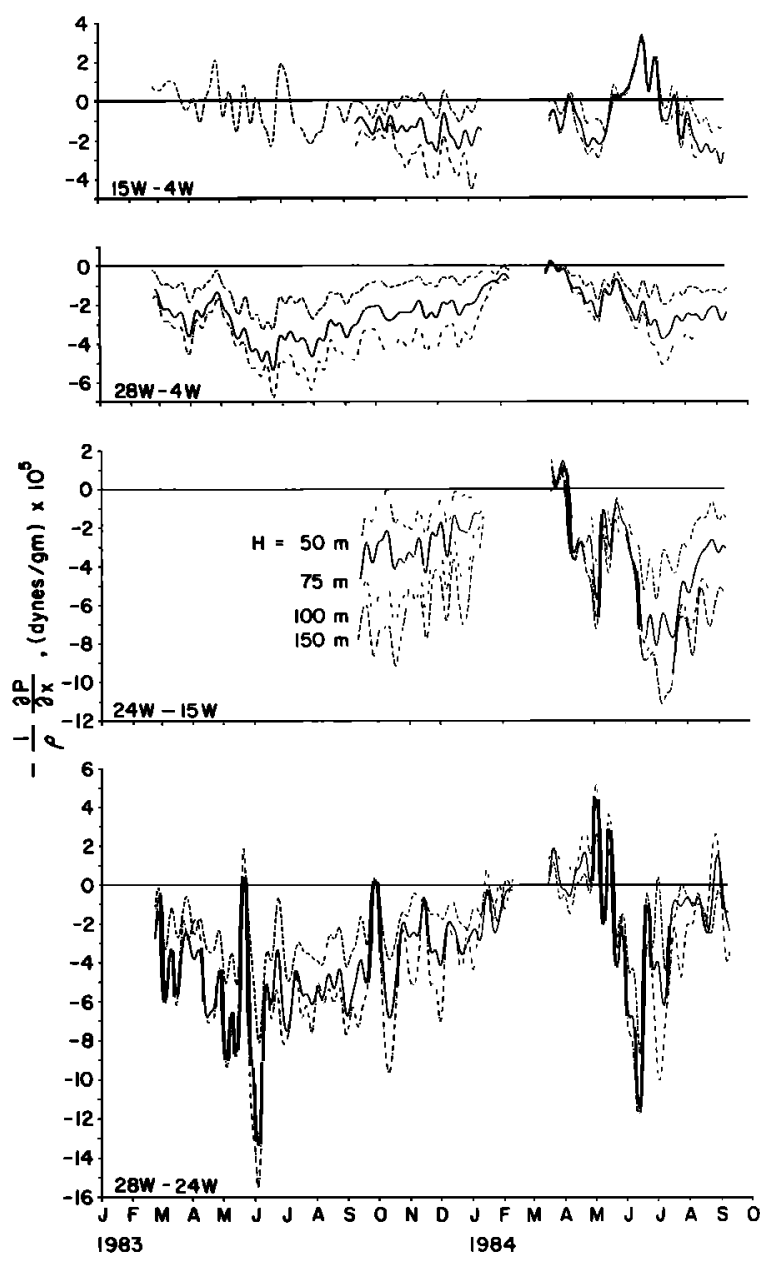

Fig. 5. Time series of the baroclinic response of the zonal pressure gradient. From bottom to top: $28^{\circ} \mathrm{W}-24^{\circ} \mathrm{W}, 24^{\circ} \mathrm{W}-15^{\circ} \mathrm{W}, 28^{\circ} \mathrm{W}-$ $4^{\circ} \mathrm{W}$, and $15^{\circ} \mathrm{W}-4^{\circ} \mathrm{W}$. The short-dashed, solid, dash-dot and longdashed lines denote series at $50 \mathrm{~m}, 75 \mathrm{~m}, 100 \mathrm{~m}$, and $150 \mathrm{~m}$, respectively. Units are $10^{-5} \mathrm{dyn} / \mathrm{g}$. Tick marks on the time axis coincide with the fifteenth day of each month. 
mark times, i.e., mid-April 1983 and mid-May 1984, for reasons previously mentioned. In a broad sense we may describe the annual cycle in the baroclinic response of the ZPG as consisting of rapid variations following rapid, large-scale changes in easterly wind stress which overshoot their intended equilibrium and then gradually relax toward it.

\section{Zonal Inhomogeneity}

The baroclinic response of the ZPG computed for the $15^{\circ} \mathrm{W}-4^{\circ} \mathrm{W}$ separation is distinctly different from the others. The 50-m record during 1983 does not show a clear annual cycle, and the records at all depths following the mid-May 1984 benchmark appear to vary out of phase with those of the $28^{\circ} \mathrm{W}$ and $15^{\circ} \mathrm{W}$ pair. This suggests that a node in the isotherm slopes was crossed between $15^{\circ} \mathrm{W}$ and $4^{\circ} \mathrm{W}$, an assertion which is consistent with the climatological dynamic height distribution shown in Figure 1.

A general impression from all of the station pairs is that the ZPG calculation is strongly dependent upon zonal position and separation except when the thermocline has approached an equilibrium state. In our records this occurs between September and December 1983, when ignoring the high frequency fluctuations and excluding the $15^{\circ} \mathrm{W}$ and $4^{\circ} \mathrm{W}$ pair, all of the pressure gradient magnitudes at equal depths are approximately the same and decrease at similar rates. Conversely, it is during the periods of rapid thermocline transitions that the ZPG is the most inhomogeneous and dependent upon station position and separation.

\section{Vertical Structure}

The vertical structure of the baroclinic response does not proceed uniformly with time. Consider the $28^{\circ} \mathrm{W}$ and $15^{\circ} \mathrm{W}$ pair. From September through December 1985, while the thermocline is nearly in equilibrium, a uniform spacing is observed between the time series at $50 \mathrm{~m}, 75 \mathrm{~m}, 100 \mathrm{~m}$, and $150 \mathrm{~m}$; i.e., the baroclinic adjustment increases monotonically with depth. This situation also occurs beyond July 1984. However, during the April through June 1984 period, while the thermocline is in transition, most of the baroclinic response takes place within the upper $50 \mathrm{~m}$ with relatively little below. Consequently, the vertical structure of the ZPG appears to be time dependent.

\section{Discussion}

Philander and Pacanowski [1981] have shown that for sufficiently slow variations in zonal wind stress the equatorial zonal pressure gradient remains in equilibrium with the forcing. However, Philander and Pacanowski [1980] and Philander [1981] show that if the wind stress changes rapidly from one state to another, the oceanic response is to overshoot the equilibrium level before relaxing to it. In a broad sense the equatorial Atlantic is subject to rapidly increasing easterlies over the western two thirds of the basin in boreal spring with a similarly rapid decrease in boreal winter.

Surface slope time series from inverted echo sounder measurements [Katz et al., 1986] show a distinct annual cycle in response to the winds with a large eastward directed surface pressure gradient force following intensification and a small value following relaxation. The baroclinic response due to the isopycnal slopes shown here generally acts in opposition to the surface slope. A westward directed force develops following intensification, and an eastward directed force develops following the relaxation. Consequently, the isopycnal slopes act as a buffer to the zonal pressure gradient force at the depth of the EUC.
This buffering effect by the isopycnal slopes has important implications on the maintenance of the EUC. For example, from late January through mid-March the results from the mooring pairs exclusive of $4^{\circ} \mathrm{W}$ indicate a reversal from a westward directed to an eastward directed pressure gradient force at the level of the EUC. The reversal implies that the pressure gradient force at the depth of the EUC exceeds that at the surface. This observation is corroborated by the results of a conductivity, temperature, and depth (CTD) survey in January-February 1984 by Hisard and Henin [1984] (see Table 1). They show that the $50 / 500$ dbar pressure gradient is larger than that of the surface. Since this reversal occurs at a time of the year when the surface dynamic topography is nearly flat [Katz et al., 1986], it could be important in maintaining the EUC during the season of weak winds.

The time dependence of the vertical structure of the baroclinic response follows the vertical position of the thermocline. Prior to the vernal intensification of easterly wind stress the thermocline is shallow and the baroclinic response is confined to the upper $50-75 \mathrm{~m}$. After the winds increase and the thermocline deepends, the baroclinic response then extends down to at least $150 \mathrm{~m}$. If the EUC core is related to the ZPG, then its vertical location should also vary over the annual cycle. An observation of this is given by Weisberg and Colin [1986].

In the review of published data we mentioned that the baroclinic response due to the sloping isopycnals effectively compensates the surface slope induced pressure gradient at depths of 75-100 $\mathrm{m}$ in the central Atlantic Ocean. The present results imply that from midsummer through early winter a westward pressure gradient force develops at $150 \mathrm{~m}$. This period coincides with the basinwide adjustment of the thermocline and quasi-steady winds, as was previously mentioned. The fact that flow at $150 \mathrm{~m}$ is eastward throughout the year [Weisberg and Colin, 1986] is consistent with Arthur's [1960] hypothesis that eastward momentum may be maintained in the lower portion of the EUC in the face of a westward pressure gradient force.

Superimposed upon the annual cycle of the baroclinic response are higher-frequency variations which are most evident in the $28^{\circ} \mathrm{W}$ and $24^{\circ} \mathrm{W}$ pair. Among these are waves with time and length scales of around 25 days and $1000 \mathrm{~km}$, respectively [Weisberg, 1984; McPhaden et al., 1984]. They give rise to thermal fluctuations between $28^{\circ} \mathrm{W}$ and $24^{\circ} \mathrm{W}$ which are nearly out of phase, thereby producing the largest extremes in the baroclinic response during 1983. Their influence upon the baroclinic response decreases with increasing zonal separation, so their effect upon the large scale ZPG appears as a local perturbation.

The rapidity of the baroclinic response following rapid, large-scale changes in wind stress implies that estimates of the ZPG from quasi-synoptic hydrographic surveys could be seriously aliased. Similar warnings have been expressed by Mangum and Hayes [1984] based on observations in the Pacific.

\section{SUMmaRY AND CONCLUSIONS}

The zonal pressure gradient along the equator is related to both surface and isopycnal slopes. Here we have presented time series of the baroclinic response of the zonal pressure gradient due to the sloping isopycnals as calculated using temperature time series obtained from surface moorings deployed during the SEQUAL and FOCAL programs. Following rapid and large-scale changes in easterly wind stress, the baroclinic response due to the sloping isopycnals was observed to rap- 
idly overshoot its intended equilibrium and then to slowly relax toward it. In so doing, it provided a buffer for pressure gradient variations at the depth of the EUC. For most of the year the isopycnal slopes opposed the surface slope. An exception occured in winter following the wind stress relaxation. The isopycnal slopes reversed and acted in concert with the surface slope to enhance the pressure gradient at the depth of the EUC over that at the surface. Such a reversal may be crucial in maintaining the EUC during a time of weak easterly wind stress.

The vertical structure of the baroclinic response varied annually with the depth of the thermocline. When the winds were weak and the thermocline was shallow, the baroclinic response was primarily effected over the upper $50 \mathrm{~m}$. After the winds intensified and the thermocline deepened, the baroclinic response extended down to at least $150 \mathrm{~m}$.

In summary, the zonal pressure gradient along the equator in the Atlantic Ocean is a complicated function of time, depth, and zonal position. Its most rapid and spatially inhomogeneous variations correspond to periods of rapidly changing easterly wind stress. Consequently, estimates of the zonal pressure gradient require continuous measurements of both the surface slope and the subsurface thermal structure.

Acknowledgments. Support for this work was provided by the Oceanography Section, National Science Foundation, grant number OCE-8211848. C. Colin of ORSTOM, Paris, and presently a visiting scientist at North Carolina State University provided the temperature data at $4^{\circ} \mathrm{W}$ for our use herein, and both he and T. Y. Tang offered helpful discussions. J. Hickman assisted with the analyses.

\section{REFERENCES}

Arthur, R. S., A review of the calculation of ocean currents at the equator, Deep Sea Res., 6, 287-297, 1960.

Austin, T. S., Variations with depth of oceanographic properties along the equator in the Pacific, Eos Trans. AGU, 39, 1055-1063, 1958 .

Bryden, H. L., and E. C. Brady, Diagnostic model of the threedimensional circulation in the upper equatorial Pacific Ocean, $J$. Phys. Oceanogr., 15, 1255-1273, 1985.

Cromwell, T., R. B. Montgomery, and E. D. Stroup, Equatorial under-current in Pacific Ocean revealed by new methods, Science, $119,648-649,1954$.

Emery, W. J., and J. S. Dewar, Mean temperature-salinity, salinitydepth and temperature-depth Curves for the North Atlantic and the North Pacific, Prog. Oceanogr., 11, 219-305, 1982.

Eriksen, C. C., An equatorial transect of the Indian Ocean, J. Mar. Res., 37, 215-232, 1979.

Garzoli, S. L., and E. J. Katz, Winds at St. Peter and St. Paul rocks during the first SEQUAL year, Geophys. Res. Lett., 11, 715-719, 1984.

Gill, A. E., Models of equatorial currents, in Proceedings of the Symposium on Numerical Models of Ocean Circulation, National Academy of Science, 364 pp., Washington, D. C., 1975.

Halpern, D., A Pacific equatorial temperature section from $172^{\circ} \mathrm{E}$ to $110^{\circ} \mathrm{W}$ during winter and spring 1979, Deep Sea Res., Part A, 27, 931-940, 1980.

Hisard, P., and C. Henin, Zonal pressure gradient, velocity and transport in the Atlantic Equatorial Undercurrent from FOCAL cruises (July 1982-February 1984), Geophys. Res. Lett., 761-764, 1984.
Katz, E. J., A note on indirect wind speed measurements from ambient noise, Geophys. Res. Lett., 1I, 726-728, 1984.

Katz, E. J., et al., Zonal pressure gradient along the equatorial Atlantic, J. Mar. Res., 35, 293-307, 1977.

Katz, E. J., P. Hisard, J. M. Verstraete, and S. L. Garzoli, Annual change of the sea surface slope along the equator of the Atlantic Ocean in 1983/84, Nature, in press, 1986.

Knauss, J., Further measurements and observations on the Cromwell Current, J. Mar. Res., 24, 205-240, 1966.

Lass, H. U., V. Bubnov, J. M. Huthnance, E. J. Katz, J. Meincke, A. De Mesquita, F. Ostapof, and B. Voituriez, Seasonal changes of the zonal pressure gradient in the equatorial Atlantic during the FGGE year, Oceanol. Acta, 6, 3-11, 1983.

Mangum, L. J., and S. P. Hayes, The vertical structure of the zonal pressure gradient in the Eastern Equatorial Pacific, J. Geophys. Res., 89, 10,441-10,450, 1984.

McPhaden, M. J., M. Fieux, and J. Gonella, Meanders observed in surface currents and hydrography during an equatorial Atlantic transect, Geophys. Res. Lett., 11, 757-760, 1984.

Merle, J., and S. Arnault, Seasonal variability of the surface dynamic topography in the tropical Atlantic Ocean, J. Mar. Res., 43, 267$288,1985$.

Metcall, W. G., A. D. Voorhis, and M. C. Stalcup, The Atlantic Equatorial Undercurrent, J. Geophys. Res., 67, 2499-2508, 1962.

Montgomery, R. B., and E. Palmen, Contribution to the question of the Equatorial Counter Current, J. Mar. Res., 3, 112-133, 1940.

Payne, R. E., Surface wind measurements in SEQUAL I, Geophys. Res. Lett., II, 719-721, 1984.

Philander, S. G. H., Equatorial undercurrent: Measurement and theories, Rev. Geophys., 11, 513-570, 1973.

Philander, S. G. H., The response of equatorial oceans to a relaxation of the trade winds, J. Phys. Oceanogr., 11, 176-189, 1981.

Philander, S. G. H., and R. C. Pacanowski, The generation of equatorial currents, J. Geophys. Res., 85, 1123-1136, 1980.

Philander, S. G. H., and R. C. Pacanowski, Response of equatorial oceans to periodic forcing, J. Geophys. Res., 86, 1903-1916, 1981.

Taft, B. A., and J. A. Knauss, The Equatorial Undercurrent of the Indian Ocean as observed by the LUSIAD Expedition, Bull. Scripps Inst. Oceanogr., 9, 163 pp., 1967.

Taft, B. A., B. M. Hickey, C. Wunsch, and D. J. Baker, Jr., Equatorial undercurrent and deeper flows in the central Pacific, Deep Sea Res., $21,403-430,1974$.

Tsuchiya, M., Seasonal variation of the equatorial zonal geopotential gradient in the eastern Pacific Ocean, J. Mar. Res., 37, 399-407, 1979.

United Nations Educational, Scientific, and Cultural Organization (UNESCO), Background papers and supporting data on the International Equation of State of Sea Water, 1980, UNESCO Tech. Pap. Mar. Sci., 38, 192 pp., 1981.

Voigt, K., Aquatoriale Understroming auch im Atlantic, Beitr. Meereskl., 1, 56-60, 1961.

Weisberg, R. H., Instability waves observed on the equator in the Atlantic Ocean during 1983, Geophys. Res. Lett., 11, 753-756, 1984.

Weisberg, R. H., and C. Colin, Upper ocean temperature and current variations along the equator in the Atlantic Ocean during 19831984, Nature, in press, 1986.

Weisberg, R. H., and T. Y. Tang, On the response of the equatorial thermocline in the Atlantic Ocean to the seasonally varying trade winds, J. Geophys. Res., 90, 7117-7128, 1985.

T. J. Weingartner and R. H. Weisberg, Department of Marine Science, University of South Florida, Saint Petersburg, FL 33731.

(Received March 7, 1986; accepted April 16, 1986.) 